\title{
THE ANNUAL MEETING IN CINCINNATI
}

The Sixty-fourth Annual Meeting of the American Mathematical Society was held in Cincinnati, Ohio on Tuesday, Wednesday and Thursday, January 28-30, 1958 in conjunction with the Annual Meeting of the Mathematical Association of America. All sessions were held at the meeting headquarters, the Sheraton-Gibson Hotel, with the exception of those on Wednesday afternoon which convened at the University of Cincinnati. The attendance was about 750 , including 547 members of the Society.

The thirty-first Josiah Willard Gibbs Lecture was delivered by Professor H. J. Muller of the Zoology Department, Indiana University, at 8:00 P.M. on Tuesday in the Roof Garden of the SheratonGibson. The title of the lecture was Evolution by mutation. The presiding officer was Professor M. H. Stone.

The Presidential Address was delivered by Professor R. L. Wilder on Wednesday at 2:00 P.M. in Wilson Auditorium with Professor Richard Brauer presiding. Professor Wilder's lecture was entitled On a certain class of topological properties.

By invitation of the Committee to Select Hour Speakers for Annual and Summer Meetings, there were two addresses. Professor Nelson Dunford spoke on $A$ survey of the theory of spectral operators at 2:00 P.M. on Tuesday, with Professor I. E. Segal presiding. Dr. C. D. Papakyriakopoulos spoke on Some problems on 3-dimensional manifolds on Thursday, with Professor E. E. Moise presiding.

A tea for the attending mathematicians and their guests was given by the University of Cincinnati on Wednesday at 4:00 P.M. in the Faculty Dining Room of the Union Building on the campus.

There was a banquet in the Roof Garden of the Sheraton-Gibson starting at 7:00 P.M. on Thursday for members of the Society. This event was made possible by the generosity of the following companies: Avco Corporation, Cincinnati Gas and Electric Company, Cincinnati Milling Machine Company, General Electric Company, International Business Machines Corporation, Procter and Gamble Company, Union Central Life Insurance Company, and Western and Southern Life Insurance Company.

There was a total of sixteen sessions at which contributed papers were presented. Presiding officers were Professor Richard Brauer, Professor R. C. Buck, Professor R. H. Cameron, Professor Samuel Eilenberg, Professor A. E. Heins, Professor J. G. Hocking, Professor Leo Katz, Professor M. H. Martin, Dr. R. J. Nunke, Professor B. J. 
Pettis, Dr. Ivar Stakgold, Professor Ernst Snapper, Professor E. H. Spanier, Professor A. E. Taylor, Professor R. M. Thrall and Professor George Whaples.

Abstracts of the papers will be published in April and June issues of the Notices of the American Mathematical Society.

The Council met on Tuesday afternoon, January 28, 1958.

The Secretary announced the election of the following ninety-nine persons to ordinary membership in the Society:

Dr. Z. B. Alterman, Weizmann Institute of Science;

Dr. R. C. Alverson, Boeing Airplane Company, Seattle, Washington;

Mr. L. C. Barajas, La Latino-Americana Seguros de Vida, Mexico;

Professor F. J. Beutler, University of Michigan;

Mr. A. T. Beyer, General Electric Company, Cincinnati, Ohio;

Professor Olivier Biberstein, Memorial University;

Mr. P. M. Blair, Humble Oil \& Refining Company, Houston, Texas;

Professor Richard Blum, University of Saskatchewan;

Dr. M. K. Brachman, Northwest Oil Company, Dallas, Texas;

Mr. Donald Bratton, Control Instrument Company, Brooklyn, New York;

Dr. W. F. Brown CONVAIR, San Diego, California:

Mr. C. M. Bruen, International Business Machines Corp., Endicott, New York:

Mr. Fernand Charrier, Biard St. Varent, Deux Sevres, France:

Mr. D. A. Clarke, University of Western Ontario;

Mr. P. A. Clavier, Zenith Radio Corporation, Chicago, Illinois;

Mr. B. J. Cohen, National Cash Register Company, Dayton, Ohio;

Professor R. J. Cormier, Northern Illinois University;

Professor Russell Cowan, University of Florida;

Mr. L. F. Cremona, Combustion Engineering, Inc., New York, New York;

Mr. J. W. Davis, Jr., Radio Corporation of America, Los Angeles, California;

Mr. G. E. Decker, Lewiston Porter Central School, Youngstown, New York;

Mr. D. D. Dix, Harvard University;

Mr. E. L. Dubinsky, Burroughs Corporation, Philadelphia, Pennsylvania;

Mr. H. L. Farris, Black, Sivalls \& Bryson, Inc., Tulsa, Oklahoma;

Dr. Melvin Ferentz, International Business Machines Corp., New York, New York;

Mr. J. F. Firkins, University of Miami;

Mr. H. J. Figge, Harry J. Figge and Associates, Inc., Des Moines, Iowa;

Professor R. C. Foster, Tri-State College;

Mr. R. B. Gray, Erie Resistor Corp., Erie, Pennsylvania;

Mr. Cyril Graze, Whitestone, New York;

Professor J. R. Hamilton, Long Island University;

Dr. W. W. Hammerschmidt, U. S. Air Force, Washington, D. C.;

Mr. W. J. Harris, University College, Ibadan, Nigeria;

Mr. J. G. Harvey, Tulane University;

Dr. G. M. Helmberg, University of Washington;

Dr. C. J. Himmelberg, III, Midwest Research Institute, Kansas City, Missouri;

Mr. R. E. Holladay, Sandia Corporation, Albuquerque, New Mexico;

Dr. Maurice Horowitz, Goodyear Aircraft Corporation, Akron, Ohio;

Professor J. M. Horvath, University of Maryland;

Mr. Taqdir Husain, Syracuse University; 
Professor Cassius Ionescu Tulcea, Yale University;

Professor Herbert Izbicki, University of Idaho;

Professor J. A. Izzo, Jr., University of Vermont;

Dr. J. G. Jewell, The Martin Company, Baltimore, Maryland;

Professor A. J. John, New Bedford Institute of Technology;

Mrs. Mary J. Johnson, University of Miami;

Mr. H. J. Jones, El Camino College;

Mr. D. W. Kahn, Yale University;

Dr. Fred Krakowski, University of California, Davis;

Mr. H. O. Kreiss, The Royal Institute of Technology, Sweden;

Mr. R. G. Krutchkoff, Columbia University;

Mr. Gustav Kuerti, Case Institute of Technology;

Professor Nin Kumasawa, Tokyo University of Fisheries;

Dr. K. S. Kunz, Schlumberger Well Surveying Corp., Ridgefield, Connecticut;

Mr. R. G. Laatsch, University of Tulsa;

Mr. W. J. Leinbach, Wake Forest College;

Mr. J. T. Leverich, Harvard University;

Mr. H. H. Love, Jr., University of Delaware;

Mr. Franklin Lyman, Brooklyn, New York;

Mr. B. J. McDonald, U. S. N. Mine Defense Laboratory, Panama City, Florida;

Mr. W. T. McKinney, CONVAIR Astronautics, San Diego, California;

Mr. G. J. Maltese, Yale University;

Mr. J. R. Micklich, New Mexico Military Institute;

Mr. K. L. Miller, Brown University;

Dr. W. L. Miranker, Bell Telephone Laboratories, Murray Hill, New Jersey;

Mr. D. E. Muir, The Martin Company, Denver, Colorado;

Professor R. S. B. Ong, University of Michigan;

Professor Aris Phillips, Yale University;

Dr. G. H. Pimbley, Jr., Los Alamos Scientific Laboratory;

Mr. H. A. Pogorzelski, Mathematical Reviews, Providence, Rhode Island;

Professor R. M. Rankin, Missouri School of Mines;

Mrs. Joanna W. Schot, David Taylor Model Basin, Washington, D. C.;

Mr. R. F. J. Schulz-Arenstorf, Army Ballistic Missile Agency, Huntsville, Alabama;

Mr. J. F. Schwab, Arlington, Virginia;

Mr. P. T. Semm, Hallicrafters Company, Inc., Chicago, Illinois;

Professor R. D. Sheffield, University of Mississippi;

Mr. L. W. Small, Yonkers, New York;

Mr. H. A. Smith, Remington-Rand UNIVAC, Philadelphia, Pennsylvania;

Dr. J. H. Smith, American University;

Professor R. J. Smith, Northern State Teachers College;

Mr. W. S. Soar, Ballistic Research Laboratories, Aberdeen, Maryland;

Professor C. E. Sperry, Alderson-Broaddus College;

Mr. A. S. Stankovich, U. S. Air Force, Washington, D. C.;

Mr. B. K. Swartz, Massachusetts Institute of Technology;

Dr. Selmo Tauber, University of Kansas;

Professor F. L. Taylor, Southern Oregon College;

Dean F. M. Tiller, University of Houston;

Professor E. H. Tompkins, Jr., North Carolina State College;

Dr. Anthony Trampus, General Electric Company, Cincinnati, Ohio;

Dr. J. P. Tull, Ohio State University; 
Mr. William Weisman, Physics Laboratory, New York, New York;

Professor J. R. Wesson, Vanderbilt University;

Mr. W. L. Wetmore, Corning Glass Works, Corning, New York;

Mr. B. E. Wicks, Aerojet-General Corporation, Sacramento, California;

Dr. J. R. Wilts, International Business Machines Corporation, Endicott, New York;

Dr. J. S. White, Minneapolis-Honeywell Regulator Company, Minneapolis, Minnesota;

Mr. D. C. Wold, Rice Lake, Wisconsin;

Dr. Basil Zacharkiw, Seton Hall University;

Mr. J. F. Zelle, Cleveland Broadcasting, Inc., Cleveland, Ohio.

It was reported that the following two hundred and seventy-three persons had been elected to membership on nomination of institutional members as indicated:

Brooklyn College: Mr. Murray Schechter, Mr. R. M. Warten.

Brown University: Mr. A. M. Duguid, Professor Ulf Grenander, Professor Michael Papadopoulos, Professor Eli Sternberg.

University of California, Berkeley: Mr. G. D. Chakerian, Mr. Richard Cleveland, Mr. M. D. Davis, Mr. E. M. Ellentuck, Mr. Vladimir Filippenko, Mr. T. E. Frayne, Mr. R. H. Homer, Mr. Hajimu Ogawa, Mr. Julius Smith, Mr. M. R. Swift, Mr. T. N. Tracewell, Mr. J. E. Weidlich, Mr. Mitsuru Yasuhara.

California Institute of Technology: Mr. P. L. Crawley, Mr. D. F. Rearick.

University of California, Los Angeles: Mr. D. G. Cantor, Mr. K. M. Ferrin, Mr. W. G. Strang, Mr. E. O. Thorp.

University of Chicago: Mr. Yasuo Akizuki, Mr. S. U. Chase, Mr. E. D. Davis, Mr. H. H. Gershenson, Mr. Martin Helling, Dr. Shin-ichi Izumi, Mr. Adam Koranyi, Mr. C. E. Linderholm, Mr. A. L. Liulevicius, Mr. Gunter Lumer, Mr. P. H. Monsky, Mr. K. R. Nagarajan, Mr. N. C. Petridis, Mr. G. N. Pinkham, Miss Eliana F. Rocha, Mr. Hwa Tsang, Mr. Stephen Wainger, Mr. N. D. Whaland, Jr.

University of Cincinnati: Mr. Hsi-ching Liu.

University of Colorado: Mr. C. E. Aull, Mr. A. A. Nafoosi, Mr. R. G. Thompson. Columbia University: Mr. J. G. Glimm, Miss Mary E. Powderly, Mr. W. W. Saffern, Mr. Shigeaki Togo, Mr. Kalathoor Varadarajan.

Cornell University: Miss Nancy L. Hannye, Mrs. Louise Hay, Mr. Anatole Joffe, Mr. Birger Lovgren.

DePaul University: Mr. W. G. Witthoft.

Duke University: Miss Ellen E. Brauer, Mr. C. H. Horsfield, Mr. E. K. Johnson, Miss Martha E. Lawrence, Mr. R. W. Llewellyn, Mr. M. J. Saadaldin, Mrs. Margaret J. Stone, Miss Nancy M. Turnbull, Mr. L. H. Williams.

University of Florida: Mr. J. F. Andrus.

University of Georgia: Mr. C. W. Patty.

Harvard University: Mr. D. M. Bloom, Mr. Harvey Brooks, Mr. R. W. Cottle, Mr. E. G. Effros, Mr. Adam Kleppner, Mr. T. B. Knapp, Rev. P. J. Knopp, S.J., Mr. J. P. McCabe, Rev. V. M. Manjarrez, S.J., Mr. J. I. Richards, Mr. George Sadowdky, Mr. S. S. Shatz, Mr. P. R. Yale.

University of Illinois: Mr. K. W. Anderson, Miss Judith A. Blankfield, Mr. J. C. McCall, Mr. L. R. McMurray, Mr. E. M. Paul, Mrs. Nancy J. Poxon, Mr. J. H. Shelly, Mr. R. N. Townsend.

Illinois Institure of Technology: Mr. David Sachs. 
Indiana University: Mr. D. L. Hanson, Mr. T. W. Ting, Mr. J. A. Wendland.

Institute for Advanced Study: Dr. J. F. Adams, Professor Also Andreotti, Mr. Pierre Cartier, Mr. Hans Grauert, Professor Michel Herve, Mr. Daniel Lacombe, Professor P. P. W. Lorenzen, Dr. Sibe Mardesic, Dr. A. I. Martin, Professor John Myhill, Dr. Dieter Puppe, Dr. W. F. Stoll, Mr. Lucien Waelbroeck.

Iowa State College of Agriculture and Mechanic Arts: Mr. I. D. Ruggles.

University of Kansas: Mr. T. J. Head, Mr. H. L. Nelson, Mr. D. E. Wilson.

Lehigh University: Mr. A. L. Hilt, Mr. C. W. Sloyer.

University of Maryland: Mr. James Conlan, Mr. G. R. Blakley, Mr. R. W. Carroll, Mr. R. C. Kline, Jr., Professor G. J. Rieger, Dr. E. P. Shelly, Mr. D. F. Templeton, Jr., Mr. G. T. Trotter.

Massachusetts Institute of Technology: Mr. J. L. Boal, Professor L. A. E. Carleson, Mr. R. J. Crittenden, Mr. H. I. Gross, Mr. M. D. McIlroy.

University of Miami: Miss Beverly L. Brechner, Miss M. J. Leslie Leitch, Mr. C. B. Stortz.

Michigan State University of Agriculture and Applied Science: Mr. B. H. Barnes, Mr. R. P. Grobe, Mr. F. J. Kosier, Mr. H. B. McClung.

University of Michigan: Mr. K. I. Appel, Mr. J. M. Beck, Mr. P. E. Bedient, Mr. T. G. Birdsall, Mr. W. D. Bouwsma, Mr. J. W. Brown, Mr. L. E. Claborn, Mr. R. L. Eisenman, Mr. L. R. Halsted, Mr. Jesse Hamman, Mr. R. R. Legault, Mr. R. E. Lewkowicz, Mr. W. D. Marsland, Jr., Mr. D. R. Schuette.

University of Minnesota: Mr. R. D. Adams, Mr. W. A. Dolid, Mr. E. O. Nelson, Mr. S. E. Spielberg, Mr. F. S. Van Vleck.

University of Nebraska: Mr. S. E. Bohn.

New Mexico College of Agriculture and Mechanical Arts: Mr. K. W. Lopp.

New York University: Miss Esther Rodlitz.

Northwestern University: Dr. M. P. Drazin, Mr. Samuel Pasiencier, Mr. S. C. Port.

Ohio State University: Mr. M. R. Hopkins, Mr. Joseph Kohler, Mr. L. R. McCulloh, Mr. M. V. K. Kenon, Mr. W. C. Nemitz, Mr. Robert Silverman.

Oklahoma State University: Mr. V. Seshadri.

University of Oregon: Miss Yvonne H. Cuttle, Mr. R. S. DeZur, Mr. R. P. Pakshirajan.

University of Pennsylvania: Mr. L. N. Bidwell, Mr. Louis Brickman, Mr. E. M. Brown, Mr. Hsin Chu, Mr. J. P. Clay, Mr. Neil Grabois, Miss Rora F. Iacobacci, Mr. Larry Mann, Miss Ruth M. Roberts, Mr. P. H. Sellers, Miss Catherine E. Shields, Mr. Paul Weinberg.

Pennsylvania State University: Miss Dorothy L. Bordner, Mrs. Mary L. Oliver. Princeton University: Mr. B. J. Birch, Mr. R. T. Bumby, Mr. A. H. Clark, Dr. D. E. Cohen, Mr. Adrien Douady, Mr. S. E. Dreyfus, Mr. G. B. Hensel, Mr. Kuno Lorenz, Mr. L. C. Mejlbo, Mr. R. W. Ritchie, Mr. F. M. Sand, Mr. H. F. Thornton, Mr. T. H. Wonnacott.

Purdue University: Mr. B. J. Boyer, Mr. F. W. Carroll, Jr., Mr. S. A. Husain, Mr. J. E. Mack, Mr. Togo Nishiura, Mr. W. E. Thompson.

Queens College: Miss Marva B. Parks, Mrs. Relita N. Rivelle.

Rice Institute: Mr. A. A. Armendariz, Mr. Alan Wilson.

Rutgers University: Dr. E. R. Gentile, Mr. J. B. Herder, Mr. J. P. Jordan, Mr.

J. C. Leavy, Jr.

College of Saint Thomas: Mr. D. W. Smith. 
University of Southern California: Mr. J. W. Bergquist, Mr. Edwin Hirs chhorn, Mr. D. R. Ryan.

Stanford University: Mr. C. K. Bradshaw, Mr. E. D. Callender, Mr. K. S. Davis, Mr. A. E. Hurd, Mr. W. R. Jones, Mr. L. H. Lanier, Jr., Mr. M. A. Seelye, Mr. D. R. Sherbert, Mrs. Betty J. Stone, Mr. Andrew Torok, Mr. L. M. Young, Mr. R. R. Weiss.

Syracuse University: Mr. S. D. Chatterji, Mr. G. F. Clements, Mr. T. S. Frank, Mr. N. J. Pullman, Mr. Eugene Rogot, Mr. J. P. van Alstyne,

University of Texas: Mr. W. D. L. Appling, Mr. E. L. Bethel, Mr. R. F. Jolly, Mr. W. A. Kirby, Mr. D. F. Riddle, Mr. J. T. White.

University of Toronto: Mr. Martin Eisen, Mr. R. K. Fosu, Mr. R. J. Pegis, Mr. Romas Mitalas, Mr. J. C. Taylor.

Tulane University: Mr. A. J. Hulin, Mr. John Selden.

University of Utah: Mr. D. A. Ford.

Vanderbilt University: Dr. Jose Gallego-Diaz.

University of Virginia: Miss Mary K. Huggin, Mr. J. G. May, Mr. W. G. May, Mr. P. E. McDougle, Miss Mary G. Rodreque.

University of Washington: Mr. J. G. Ceder, Miss Dorothy J. Christensen, Mr. A. W. Marshall.

Washington University: Mr. D. A. Higgs.

Wayne University: Mr. R. F. Pavley.

University of Wisconsin: Mr. G. D. Allaud, Mr. S. J. Doorman, Mr. Herbert Hetherington, Mrs. Ruth Iscol, Mr. D. R. McMillan, Jr., Mr. M. M. Nanda, Mr. G. M. Nielsen, Mr. R. A. Schutt, Mr. R. D. Sinkhorn, Miss Patricia A. Tucker, Miss Sandra Weinstein, Mr. C. R. B. Wright.

Yale University: Mr. C. A. McCarthy, Mr. Neill McShane, Mr. R. A. Scoville, Mr. P. C. Shields, Miss Dorothea K. Stillinger, Mr. W. W. Tait.

The Secretary announced that the following had been admitted to the Society in accordance with reciprocity agreements with various mathematical organizations: Deutsche Mathematiker-Vereinigung: Professor G. M. Koethe, Dr. Horst Lippmann, Professor Hans Rohrbach, Professor Robert Sauer; London Mathematical Society: Professor J. H. H. Chalk, Mr. G. E. H. Reuter, Professor W. W. Sawyer; Société Mathématique de France: Dr. Jacques Neveu, Mr. Francois Norguet, Professor Makoto Ohtsuka, Professor J. G. Teixeira; Svenska Matematikersamfundet: Mr. S. Y. Christofferson, Professor T. H. Ganelius, Professor L. V. Hormander; Wiskundig Genootschap te Amsterdam: Dr. Jacobus Verhoeff.

The following appointments by the President were reported: as a Committee to Review the Arrangements between the Society and the Johns Hopkins Press: Harish-Chandra, A. E. Meder, A. W. Tucker; as a Committee on Expository Books: Lipman Bers, S. Bochner, A. M. Gleason, E. J. McShane, Deane Montgomery; to the Committee to Study the Economic Status of Teachers: A. A. Albert, David Blackwell, J. W. Green, Richard Bellman (other members: Wallace Givens, C. H. Fischer, H. M. Schaerf); as a Committee to Make Noninations for 
the Executive Committee for 1958: S. S. Cairns, Chairman, Edwin Hewitt, B. O. Koopman, W. M. Whyburn; as an Arrangements Committee for the Summer Meeting, 1958: C. B. Thoman, Chairman, J. H. Curtiss, Philip Franklin, H. M. Gehman, F. B. Hildebrand, Norman Levinson, Hartley Rogers, Jr., R. D. Schafer; as a Committee to Nominate Officers and Members of the Council for 1959: George Mackey, Chairman, Herbert Busemann, Marshall Hall, B. J. Pettis, G. de B. Robinson; as members of Committees to Select Hour Speakers (terms to expire December 31,1959): Summer and Annual Meetings: R. L. Wilder (Committee will consist of J. W. Green, Chairman, Einar Hille, R. L. Wilder); Eastern Meetings: D. C. Spencer, (Committee will consist of R. D. Schafer, Chairman, Warren Ambrose, D. C. Spencer); Western Meetings: Raoul Bott, (Committee will consist of J. W. T. Youngs, Chairman, R. C. Buck, Raoul Bott); Far Western Meetings: H. F. Bohnenblust (Committee will consist of V. L. Klee, Chairman, Charles Loewner, H. F. Bohnenblust); Southeastern Meetings: A. D. Wallace (Committee will consist of G. B. Huff, Chairman, O. G. Harrold, A. D. Wallace); to the Applied Mathematics Committee for a three year term beginning January 1, 1958: Brockway MacMillan, S. M. Ulam; as Chairman for 1958: Garrett Birkhoff (Committee to consist of Garrett Birkhoff, Chairman, R. E. Bellman, R. S. Burington, Shizuo Kakutani, Brockway MacMillan, S. M. Ulam); as Chairman of the Committee on Translations from Russian: J. V. Wehausen; reappointed to the Committee for a three year period beginning July 1, 1957: R. E. Bellman, Hans Samelson (Committee will consist of J. V. Wehausen, Chairman, R. P. Boas, R. E. Bellman, Irving Kaplansky, Hans Samelson); to the Joint Committee on Places of Meeting for a three year term beginning January 1, 1958: G. R. MacLane (Committee to consist of R. M. Thrall, Chairman, R. D. Schafer, G. R. MacLane); as Tellers for the, election of officers and members of the Council for 1958: W. G. Lister, Chairman, D. A. Buchsbaum, R. T. Shield.

The following appointments to represent the Society were reported: at the installation of Edwin Cameron Clarke as President of Geneva College: Professor Wray G. Brady; at the inauguration of Val $\mathrm{H}$. Wilson as President of Skidmore College: Edwin Brown Allen; at the inauguration of Richard Glenn Gettell as President of Mt. Holyoke College: Neal McCoy; at the inaguration of S. W. Martin as President of Emory University: J. H. Wahab.

The Secretary reported that the following have accepted invitations to deliver hour addresses: at the University of Miami in November, 1957: Hans Rohrbach; at the Annual Meeting in Cincinnati, 
January, 1958: Nelson Dunford and C. D. Papakyriakopoulos; at Hunter College in February, 1958: Louis Nirenberg; at Stanford University in April, 1958: W. W. Rogosinski; at Columbia University in April, 1958: J. C. Moore and I. M. Singer; at Chicago in April, 1958: George Whaples.

The Council voted that the Summer Meeting in 1961 should be held at Oklahoma State University.

The Council voted to set Meetings at Evanston, Illinois in November, 1958; the University of Wisconsin, Milwaukee, in November, 1961; at Stanford, California, on April 18-19, 1958; at Durham, North Carolina, on November 28-29, 1958.

The Council voted to set Council meetings April 25, 1958, in New York, and at the Summer and Annual Meetings.

It was reported that Professor R. S. Pierce will serve as Acting Associate Secretary for the West Coast Area while V. L. Klee is abroad in 1958-1959.

The Report of the Editorial Committee of the Bulletin was received. The 1957 Bulletin contained only 425 pages; however it is anticipated that it will contain 625 pages in 1958 , and this number was authorized.

With respect to the new department of short announcements in the Bulletin, two actions were taken. The editors were authorized to print the following announcement at the beginning of the new section: The purpose of this department is to provide early announcement of significant new results, with some indications of proof. Although ordinarily a research announcement should be a brief summary of a paper to be published in full elsewhere, papers giving complete proofs of results of exceptional interest are also solicited.

The Council also voted that the Editorial Committee of the Bulletin should have the right to reject papers communicated by Council members.

The Council voted to authorize the Proceedings to publish 1006 pages in 1958, and the Transactions to publish three volumes of approximately 550 pages each. It was also voted to recommend to the Trustees that four volumes of the Transactions be published in 1959 if this can be financed.

The Council voted to approve the recommendations of the Colloquium Editorial Committee that the Colloquium volumes by Jackson, Stone, and Paley-Wiener be reprinted, that Garrett Birkhoff be authorized to prepare a revision of Lattice theory, and that S. S. Chern be the Colloquium lecturer in 1960.

The Report of the Mathematical Reviews Editorial Committee 
was accepted. The Council recommended that the Editorial Committee look into what incentives could be offered to reviewers to increase the number of reviewers and quality of reviews.

The Committee on Russian Translations reported that 1500 pages were selected for translation in 1957 , and that it anticipates about the same number in 1958.

The Invitations Committee for the 1958 Summer Institute on Surface Area reported that the Institute will be held at Bowdoin College, in Brunswick, Maine. The Council approved the recommendation by the Organizing Committee for Summer Institutes that an Institute in Number Theory be arranged in 1959.

The Applied Mathematics Committee recommended that a Summer Seminar in applied mathematics be held in 1959 entitled "Modern Physical Theories and Associated Mathematical Developments." This recommendation was approved by the Council.

It was voted that, subject to the concurrence of the Mathematical Association and the Society for Industrial and Applied Mathematics, the Joint Committee on Employment Opportunities be discharged and the Employment Register be handled by the Headquarters Office of the Society under the policy supervision of a committee consisting of one member from each organization. After the 1958 April Meetings, the Register will be displayed at Summer and Annual Meetings only.

The Council voted that the Society should become a member of the Conference Organization of the Mathematical Sciences, the other members of which are the Mathematical Association of America, the Association for Symbolic Logic, the Institute of Mathematical Statistics, the National Council of Teachers of Mathematics, and the Society for Industrial and Applied Mathematics. This organization replaces the Policy Committee for Mathematics, whose membership was the same. The purpose of the organization is to assist the member organizations in areas of common interest of several of them.

The Annual Business Meeting of the Society was held at 3:15 P.M. on Wednesday, January 29 in Wilson Auditorium at the University of Cincinnati. The Secretary reported briefly on the affairs of the Society.

At the annual election of officers, which was completed by mail ballot on November 10, 1957, approximately 2000 ballots were received, and the following were elected to office:

President Elect (one year), E. J. McShane.

Vice Presidents (two years), Garrett Birkhoff and N. E. Steenrod. 
Associate Secretaries (three years), V. L. Klee, G. B. Huff, and J. W. T. Youngs.

Member of the Editorial Committee of the Bulletin (three years), E. E. Moise.

Member of the Editorial Committee of the Proceedings (three years), P. R. Halmos.

Member of the Editorial Committee of the Transactions and Memoirs (three years), Samuel Eilenberg, G. P. Hochschild.

Member of the Editorial Committee of the Colloquium Publications (three years), Salomon Bochner.

Member of the Editorial Committee of the Mathematical Reviews (three years), J. L. Doob.

Member of the Editorial Committee on Mathematical Surveys (three years), Irving Kaplansky.

Member of the Committee on Printing and Publishing (three years), E. F. Beckenbach.

Board of Trustees (five years), H. F. Bohnenblust.

Members-at-Large of the Council: R. H. Bing, L. H. Loomis, I. E. Segal, P. C. Rosenbloom, Walter Rudin.

The ordinary membership of the Society at the end of 1957 was 5711 , including 580 nominees of institutional members and 31 life members. There are 140 institutional members and 3 corporate members. The total attendance of members at all 1957 meetings (including this Annual meeting) was 3304, including 2441 registrations of members of the Society. The number of papers presented was 657 . There were 15 hour addresses, 1 Gibbs Lecture, 1 set of 4 Colloquium Lectures, 1 Presidential Retiring Address, 10 papers at an Applied Mathematics Symposium, and 11 papers at a Symposium on Game Theory.

In response to a question from the floor, the Secretary reported on the status of the Society's efforts to assist Dr. Paul Erdös to obtain a re-entry permit into the United States. It was reported that Dr. Erdös is in Canada, and that the Secretary has made all efforts to see that while there he has the service of the lawyer whom the Society has retained. It is not proposed to retain the lawyer after expiration of present arrangements. 